\title{
Homology modelling of metabotropic glutamate receptor 2
}

\author{
S Mordalski ${ }^{i^{*}}$, T Kosciolek', A Ravna², I Sylte², AJ Bojarski ${ }^{1}$ \\ From 6th German Conference on Chemoinformatics, GCC 2010 \\ Goslar, Germany. 7-9 November 2010
}

Many studies show involvement of metabotropic glutamate receptors (mGluRs) in synaptic excitation transudation. The mGluR family consists of eight proteins divided into three groups corresponding to sequence similarities, pharmacology and physiological role. These groups are: I (mGluR1, -5), II (mGluR2, -3) and III (mGluR4, -6, -7, -8). Group II lies in field of our interest due to its potential as therapeutic target for stroke and pain drugs. Primary goal of this research is to create viable virtual model of transmembrane domain of mGluR2 receptor capable of binding reference ligands. This model will be used for further research.

Our approach is based on homology modeling. Rhodopsin crystal structure has been used as a template for creating mGluR2 models. Due to inconsistencies between sequence alignments found in literature our alignment has been prepared basing on experimental secondary structure prediction for mGluR1 and mGluR3 [1]. So created models were then tested against available mutational data $[2,3]$ and by flexible docking of known active/inactive compounds.

\section{Acknowledgments}

The study was partly supported by a grant PNRF-103-Al-1/07 from Norway through the Norwegian Financial Mechanism.

\section{Author details}

${ }^{1}$ Department of Medicinal Chemistry, Institute of Pharmacology Polish Academy of Sciences, Krakow, 31-343, Poland. ${ }^{2}$ Medical Pharmacology and Toxicology, Department of Medical Biology, Faculty of Health Science, University of Tromsø, N-9037 Tromsø, Norway.

Published: 19 April 2011

\footnotetext{
* Correspondence: stefanm@if-pan.krakow.pl

'Department of Medicinal Chemistry, Institute of Pharmacology Polish

Academy of Sciences, Krakow, 31-343, Poland

Full list of author information is available at the end of the article
}

\section{References}

1. Pin JP, Joly C, Heinemann SF, Bockaert J: Domains involved in the specificity of $\mathrm{G}$ protein activation in phospholipase $\mathrm{C}$-coupled metabotropic glutamate receptors. EMBO J 1994, 13:342-348.

2. Hu J, McLarnon SJ, Mora S, Jiang J, Thomas C, Jacobson KA, Spiegel AM: A region in the seven-transmembrane domain of the human $\mathrm{Ca}^{2-}$ receptor critical for response to $\mathrm{Ca}^{2-}$. J Biol Chem 2005, 280:5113-5120.

3. Yanagava M, Yamashita T, Shichida Y: Activation Switch in the Transmembrane Domain of Metabotropic glutamate receptor. Mol Pharmacol 2009, 76:201-207.

doi:10.1186/1758-2946-3-S1-P40

Cite this article as: Mordalski et al:: Homology modelling of

metabotropic glutamate receptor 2. Journal of Cheminformatics 20113 (Suppl 1):P40.

\section{Publish with ChemistryCentral and every scientist can read your work free of charge \\ "Open access provides opportunities to our colleagues in other parts of the globe, by allowing anyone to view the content free of charge." \\ W. Jeffery Hurst, The Hershey Company. \\ - available free of charge to the entire scientific community \\ - peer reviewed and published immediately upon acceptance \\ - cited in PubMed and archived on PubMed Central \\ - yours - you keep the copyright \\ Submit your manuscript here: \\ http://www.chemistrycentral.com/manuscript/

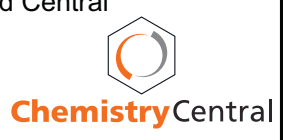

